\title{
Article \\ Served on a Plate: Engraved Sources of San Diego de Alcalá's 'Miraculous Meal' for the Franciscans of Santiago, Chile (ca. 1710)
}

\author{
Catherine Burdick
}

Citation: Burdick, Catherine. 2021. Served on a Plate: Engraved Sources of San Diego de Alcalá's 'Miraculous Meal' for the Franciscans of Santiago, Chile (ca. 1710). Arts 10: 30. https: //doi.org/10.3390/arts10020030

Academic Editor: Alena Robin

Received: 26 February 2021

Accepted: 20 April 2021

Published: 29 April 2021

Publisher's Note: MDPI stays neutral with regard to jurisdictional claims in published maps and institutional affiliations.

Copyright: (C) 2021 by the author. Licensee MDPI, Basel, Switzerland. This article is an open access article distributed under the terms and conditions of the Creative Commons Attribution (CC BY) license (https:// creativecommons.org/licenses/by/ $4.0 /)$.
Centro de Investigación en Artes y Humanidades, Universidad Mayor, Santiago 8380453, Chile; catherine.burdick@umayor.cl

\begin{abstract}
There exists a consensus in academic literature regarding the centrality of engraved prototypes for the production of colonial paintings in the Spanish Americas. In Peru, these artistic models were written into legal contracts between painters and clients. An examination of the notarial contracts produced in Cusco from 1650 to 1700 suggests that prototypes in a variety of formats were not only central to artistic professional practice, but that adherence to their images may have provided one motive for entering into such agreements. This study leans upon the centrality of Flemish print sources to confirm the attribution of a partial canvas at the Pinacoteca Universidad de Concepción, Chile as an episode of the series on the life of Diego de Alcalá (c. 1710) in Santiago, Chile. Commissioned from Cusco by the Franciscans of Santiago, the status of the hagiographic cycle as the most extensive ever produced on the subject of this missionary saint dictates that a multiplicity of sources was necessary for its creation. By identifying two engravings that served as its models, this study recovers the subject of this painting as a miracle that sustained Diego during an arduous journey.
\end{abstract}

Keywords: colonial paintings; engravings; Diego de Alcalá; Cusco; Santiago de Chile

\section{Introduction}

The study of colonial painting in the southern Andean sphere should take into consideration the breadth of the imported and local sources that informed its creation, including the Flemish prints that arrived to South America on Spanish galleons (Dean 1996). Engraved images, particularly those produced in Antwerp, have emerged as a productive inroad for comprehending how the circulation of styles and themes between Europe and the Americas supported the enormous need for religious iconographies in the Viceroyalty of Peru. When Italian and Spanish painters arrived to Lima, Cusco, and other southern Andean artistic centers during the late 1500s and early 1600s, they introduced into local practice a longstanding European tradition of consulting printed models for compositional arrangements and figural poses (Cruz de Amenábar 1986, pp. 53-59; Ojeda di Ninno 2009; Wuffarden 2014a, 2014b). Engravings were also deployed throughout Latin America during the sixteenth century for purposes of didacticism and conversion, for instance friars such as Franciscan Diego Valadés lauded such images as mechanisms for and proof of indigenous acceptance of Catholicism and Spanish colonialism (Donahue-Wallace 2008). In recent years, the study of the visual arts of the Spanish Americas through their imported sources has gained momentum, thereby enriching our understanding of the global circulation of iconographies and materials (Porras 2016). Archival records such as notarial contracts provide evidence that patrons provided images as models for emulation, many of which were engraved (Dean 1996; Verdi Webster 2017, p. 46). One benefit of focusing upon the itinerant images on paper that inspired colonial Andean art is their potential role for the thematic recovery of paintings that have suffered the ravages of time or have been disconnected from their original contexts of production and display. With this in mind, in 
what follows, I lean upon the centrality of Flemish prints in the Andean painting tradition in order to identify the subject of a partial canvas in Chile.

A charming cropped oil painting titled Monks Beneath a Tree (Monjes bajo un árbol) in the collection of the Pinacoteca Universidad de Concepción has been attributed on stylistic grounds to the hagiographic cycle representing the life of Diego de Alcalá at the Museo de Arte Colonial de San Francisco in Santiago (Figure 1; Pinacoteca Universidad de Concepción 2011). Carried out in c. 1710 by an unknown workshop in Cusco and comprised of at least forty-seven sequentially-numbered episodes executed on linen, the series is the most extensive to have ever been produced on the subject of this fifteenthcentury Spanish saint. Without any single precursor in Europe or the Americas upon which the entire cycle could have been based, many of its episodes had no direct prototype at all. Hence in the course of its creation, its anonymous artists consulted an astonishing array of printed and perhaps painted models; to mention an illustrative example, a Jesuit print depicting a new method for measuring longitude was the source for a painting showing Diego's stormy passage in the Canary Islands. While we currently lack documentation to confirm that Franciscan clients in Santiago indeed provided models for the creation of the Diego de Alcalá cycle, a contract produced in Cusco that formalized a similar commission permits us to understand how such an agreement might have been structured to include engraved prototypes for emulation; in 1691, Franciscan friar Diego de Ayala commissioned indigenous master painters Juan Inca Raurahua and Juan Sinchi Roca to "produce four dozen paintings of different dimensions that conform to the models given by said (friar) and which are to be finished within three months ... paying them six pesos for each canvas" (Cornejo Bouroncle 1952, p. 113). ${ }^{1}$ In what follows, I contend that a fruitful method for recovering the subject of the partial canvas in Concepción is through the identification of the engraved prototypes that guided its completion, thereby filling a gap in this remarkable and understudied cycle of colonial paintings.

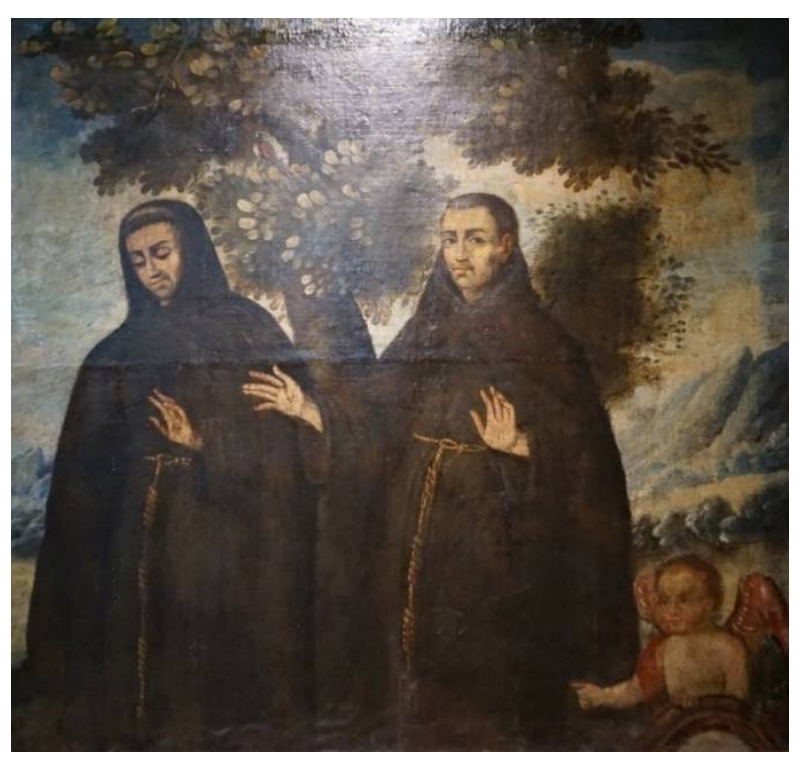

Figure 1. Anonymous workshop at Cusco. Monjes bajo un árbol (Monks Beneath a Tree). c. 1710. Oil on canvas. $112.5 \times 116 \mathrm{~cm}$. Pinacoteca Universidad de Concepción, Chile. Artwork in the public domain according to Chilean copyright law. Author photograph.

The protagonist depicted in this cropped canvas, Diego de Acalá, was born in c. 1400 at the port town of San Nicolás near Seville (Vega 1988, pp. 2-4). Upon joining the Order

1 As John Alan Crider has observed (1991, pp. 66-67), an interesting feature of this contract is that friar Diego de Ayala does not appear in Franciscan membership records of Cuzco between 1680 and 1710, leading him to surmise that the forty-eight paintings by Juan Inca Raurahua and Juan Sinchi Roca may have been produced for export. 
of the Friars Minor, Diego was hastened to the Canary Islands as part of the initial wave of Spanish imperialization. He returned to Spain in perhaps 1449 and briefly settled near Seville before attending the Roman jubilee of 1450 . His later years were passed in penitence at Alcalá de Henares and upon his death in 1463, his body was interred there beneath the high altar of the Franciscan church. Over a century later in 1588, Diego was canonized by Pope Sixtus V at the request of King Philip II of Spain, who credited the friar with posthumously healing his eldest son don Carlos of a life-threatening head injury (Villalon 1995). In the wake of his canonization, Diego de Alcalá commanded a large following in Spain as well as in the Spanish Americas. For his role as the first Counter Reformation saint, visualizations of his life and miracles were turned out by celebrated artists throughout Catholic Europe, among them Bartolomé Esteban Murillo, Francisco de Zurburán, Annibale Carracci, and Maarten de Vos (Zimmerman 1994, pp. 54-55). His iconographies were also popularized in the Spanish Americas, particularly in California, Mexico and Peru (Nolan 1978; Chichizola Debernardi 1983, p. 155; Schenone 1992, pp. 250-60).

The painting fragment under study contributed to the end of this artistic wave, and the cycle to which it pertains is understood to have been commissioned by the Franciscans of Santiago in c. 1710 to adorn the corridors of their Colegio San Diego de Alcalá. Located at the current site of the Universidad de Chile, this grade school opened its doors in 1681 to talented male students drawn to the priesthood and to disseminating Catholic doctrine in southern Chile (Iturriaga Carrasco 1990, pp. 9-10). With this impressionable young audience in mind, the artists of the Diego de Alcalá series fashioned a compelling behavioral model for generations of formative missionaries of the Franciscan Order. In 1812 or shortly thereafter, when this school was appropriated in support of the Independence movement, its paintings were likely rehoused at the nearby Franciscan Convent of Our Lady of Succor (El Convento de Nuestra Señora del Socorro) located a few blocks east (Iturriaga Carrasco 1990, pp. 31-32). Supporting this idea, the series resurfaces in early twentieth-century inventories maintained at this convent, thereby confirming that in 1920 and 1925 the complete cycle of "oil paintings on the life of S. Diego" ("cuadros al óleo de la vida de S. Diego") was displayed in the corridors that wrap around the patio garden (Díaz 1920; González 1925). When the Museo de Arte Colonial de San Francisco was founded at this convent in 1969, the series on the life of Diego de Alcalá was folded into this museum's collection.

Despite its noteworthy place in colonial Andean art history as the most extensive set of images ever produced on the first Counter Reformation saint, the cycle of San Diego de Alcalá has received little scholarly interest and is virtually unknown outside of Chile. Local art historians who have considered this series include Hernán Rodríguez Villegas and Isabel Cruz de Amenábar, who together published its history under the nom de plume Hernán Marcos Mira (1977) to publicize its exhibition at Santiago's Museo de Bellas Artes. ${ }^{2}$ A subsequent iconographic study of the series was completed by Mebold Koenenkamp (2010, pp. 119-73) as part of a two-volume catalog on the holdings of the Museo de Arte Colonial de San Francisco. Finally, an unpublished manuscript penned in 2017 by Mari Carmen García-Atance de Claro (n.d.) examines these paintings as visualizations of Diego's attributes and miracles. None of the aforementioned studies acknowledge the partial canvas in the collection of the Pinacoteca Universidad de Concepción. In what follows, I aim to contribute to existing scholarship on the San Diego cycle in Santiago, Chile by identifying the subject of the only known painting fragment pertaining to this series. To this end, in what follows, I identify two engraved sources that allow me to recover its subject and to propose some features of its composition which are no longer present. The identification of this the cropped painting as a minor theme in the life of Diego de Alcalá not only provides us with a more complete narrative for this saint, but also helps us to understand how, faced with a subject lacking a rich visual tradition, painters of Cusco employed print sources to construct an extensive body of images that were relevant to their own requirements and contexts.

2 Isabel Cruz de Amenábar (1984, pp. 39-40) also briefly described the San Diego de Alcalá series, noting its uneven quality. 


\section{Patrons and Their Prototypes in Cusco's Notarial Contracts, 1650-1700}

In advance of presenting the engraved sources that, as I will argue, served as prototypes for the cropped painting in Concepción, it is prudent to examine the archival record in order to better understand the scope and format of artistic models, how they were sourced as well as their broad relevance for professional artistic practice in colonial Cusco. While art historians engaged in the artworks of the Viceroyalty of Peru have long held paintings and their engraved prototypes side for side for comparison, comparatively few have delved into archival resources to establish the critical place of models in shaping local artistic tradition. Among a handful of notable exceptions, Mesa and Gisbert (1962) as well Damian (1995) have consulted these contracts to identify active painters in Cusco, and Carolyn Dean (1996, p. 98) observes that a standard contract for this town refers to an engraving or print which the artist was to consult. Hyman (2017, p. 108; note 30) leans upon colonial Peruvian contracts in support of his argument that the dispersal of prints across the Atlantic and their reproduction in the Americas could, for local artists, shake off their original contexts of production and authorship. Verdi Webster (2016, pp. 44-45; 2017, p. 46) has identified evidence in notarial contracts of Quito, Ecuador that patrons similarly supplied estampas (prints) to artists for emulation. While these studies confirm that artistic prototypes supplied by clients were written into notarial contracts in at least two colonial centers, a closer examination of these contracts between patrons and artists working in Cusco is valuable for determining the diverse formats that a model could comprise, and for arriving to a more nuanced understanding of their role(s). While such focus upon copying practices might be taken to implicitly privilege European sources, I would argue that in fact a close examination of artistic contracts can also constitute a decolonial approach that reveals significant differences between supplied sources and the works they inspired, thereby exposing the profound creativity of local artistic professionals.

Of course, a valuable resource for examining the artistic contracts of Cusco is the corpus of archival documents that was located and transcribed by Jorge Cornejo Bouroncle. ${ }^{3}$ Previous scholarship has systematically examined this set of contracts as an inroad to recovering diverse aspects of professional artistic practice in Cusco, ranging from the upward professional mobility of indigenous painters (Crider 1991) to the socio-economic inequalities inherent in their wages (Cohen-Aponte 2017). The present study consults the contracts produced between clients and artists for approximately the years 1650-1700. This span marks an era of artistic and architectural restoration following the devastating earthquake that struck Cusco on 31 March 1650. As I contend, the contractual records produced during this restoration era shed light on unresolved issues surrounding artistic copying, and in this way, lay forth the professional artistic practices that certainly informed the production of the Diego de Alcalá series for the Franciscans of Chile.

It is known that patrons routinely provided images to guide commissions, and a close look at the archival record for Cusco confirms this. A contract of 1671 reveals that master painter Lorenzo Sánchez de Medina received engravings that were to serve as the models for seven canvases to be completed for the confraternity of the Holy Sacrament of the parish of the Hospital de Naturales (Cornejo Bouroncle 1952, p. 105). A contract issued in 1704 reveals that master painter and indigenous noble don Felipe de Mesa of the parish of San Cristóbal entered into an agreement with mayor Phelipe Sicos to produce "small and large canvases" that conformed to the prints supplied by his client (Cornejo Bouroncle 1960, pp. 17-18, 259). In an unusual twist, upon the sale of these works the proceeds of their business venture were to be divided equally. In 1661 master painter Francisco Arias was commissioned by vicar Gaspar Carros y Zegara to produce artworks for the parish of Marcapata. Their contract stipulated that Arias was to adhere to the images provided by the vicar in the creation of paintings and bultos, or devotional sculptures (Cornejo Bouroncle

\footnotetext{
Jorge Cornejo Bouroncle's transcriptions were initially published in installments during the 1950s in Revista del Archivo Histórico del Cuzco (Universidad Nacional del Cuzco). In 1960, this body of contracts was reissued as Derroteros de arte cuzqueño: Datos para una Historia del Arte en el Peru. Unless otherwise noted, subsequent references to contracts derive from Cornejo Bouroncle's article of 1952 (for the years 1650-1700), as well as from his 1960 publication.
} 
1952, p. 92; 1960, p. 62). In 1696 Gerónimo de Málaga, together with unnamed colleagues or with members of his workshop, was contracted by the Mercedarians to produce sixty paintings on the lives of Saint Pedro Nolasco and the Virgin, taking as models the paintings at the Convento de Merced at Cusco (Cornejo Bouroncle 1952, p. 135).

Open questions regarding the artistic prototype for colonial Cusco include their range of media. While art historians have long understood that engravings and even paintings served as models for artists of the Spanish Americas, contracts confirm that the artistic landscape of late-seventeenth-century highland Peru was also routinely informed by drawings and plans. In Cusco, the formulaic notarial contracts for the production of retablos (altarpieces) provides evidence that drawings and plans were almost invariably supplied by (and in some cases created by) clients as models for their production. A contract of 1661 conveys that Jesuit priest Juan Arias personally created the plan that was provided to master joiner Martín Torres to direct his facture of a cedar retablo for the Church of the Society of Jesus (Cornejo Bouroncle 1952, p. 92). In 1670, a contract instructed Diego Martínez to assemble a retablo for the Franciscan confraternity of Jesus of Nazareth "from the same traza (sketch or plan) and drawing signed before the notary" (Cornejo Bouroncle 1952, pp. 104-5). A contract of 1694 expresses an unusual instance in which a model created by master joiner Juan Esteban Álvarez visualized the very retablo that he would produce for his client, friar Juan de Arbides of the Church of San Juan de Dios. By signing this drawing, Arbides ostensibly authorized its validity as a legal prototype (Cornejo Bouroncle 1952, pp. 126-28). Examined contracts indicate that acceptable formats for an artistic prototype could extend in unpredictable ways beyond engravings, paintings and even drawings. In preparation for the Corpus Christi festival of 1691, master architect Pedro de Aranda was apparently provided a map or chart (mapa) to guide his construction of a sumptuous triumphal archway for Cusco's main plaza (1952, pp. 112-13). As is posited by these contracts, the longstanding scholarly focus upon the engraved source may overlook a vast realm of other artistic influences.

A further question that remains unclear is the degree to which contracts were capable of expressing a patron's desire to alter sourced models. For the case of Cusco during the second half of the seventeenth century, some clients submitted prototypes as mere points of departure from which further instructions were provided. A contract of 1694 indicates that Jesuit priest Joseph Manuel de Elgueta of the Colegio de San Borja submitted a print to master painter Marcos de Rivera (Marcos Ribera) to inform a painting of Saint Xavier at the moment of his death. The contract specified that in addition to (or alternately derived from) this print, Ribera was to include in his canvas figures of Christ, the Virgin and angels receiving Xavier's soul (Cornejo Bouroncle 1952, pp. 128-31). Ribera was also instructed by the same Jesuit to complete a painting showing Ignacio de Loyola wounded at the battle of Pamplona, to be reproduced "as it is on the main altar of the Cuzco church", but with its figures (perhaps specifically its main figures) painted larger in accordance with the scale of the commission (Cornejo Bouroncle 1952, pp. 128-29). In a fascinating notarial contract of 1651, the parish of Saint Cristóbal in Cusco contracted ladino (a Spanishspeaking indigenous person) silversmith Juan Ramos to produce a crown for a sculpture representing the Assumption of the Virgin. Their contract stipulated that Ramos was to design the silver crown by copying that of the image of Our Lady of Loreto in the Jesuit Chapel of the Indians, yet in addition Ramos was alter this design in accordance with a drawing shown to him by don Lázaro Quispetopa Inga, a parishioner of the aforementioned chapel (Cornejo Bouroncle 1952, pp. 75-76). As these contracts convey for the case of Cusco, patrons routinely requested alterations to the iconography, composition or scale of a provided model in order to achieve a unique or more desirable product.

A final question that merits consideration is the potential weight, in legal terms, of an artistic prototype that was written into a notarial contract. Central to this question, a number of the contracts under study legally defined a finished work as one which had successfully reproduced its model. This is particularly evident in transactions for retablos, which instruct "the completed retablo will correspond to the form of the drawing" made by 
the artist and signed by the patron "leaving nothing out of the drawing" (Cornejo Bouroncle 1952, p. 126), and a work "completed ... to satisfaction" will adhere to "the form and manner of the (provided) drawing" (Cornejo Bouroncle 1952, pp. 70-71). Susan Verdi Webster has observed for the case of colonial Quito that because patrons were obligated to bear the cost of notarial contracts, they likely entered into such contractual relationships with artists when the magnitude of the work or its cost merited this expense. The archival records for colonial Cusco may reflect a similar pattern, but I would add that a patron's firm desire to obtain a copy or derivation of a supplied model was also a likely motive for taking on this expense. In other words, it was by means of the notarial contract that a client could enforce an artist's reproduction of a supplied prototype, in any format and following stipulated adjustments, in exchange for payment. From the standpoint of the artist, notarial contracts also eliminated uncertainty and reduced potential conflict by ensuring that a client could not back out of or alter a commission in progress.

Despite archival evidence that the artists of Cusco were routinely compelled to reproduce prototypes supplied by patrons, it would be a mistake to presume that the members of Cusco's artistic workshops lacked legal discretion or creative liberty. As we will see in case of the cropped image of Diego de Alcalá in Concepción, artists reinterpreted supplied models in a myriad of ways, for instance by grafting models together in single scenes, selecting color palettes and adding regional stylistic flourishes. In what follows, I contend that the reliance upon models as expressed in Cusco's colonial notarial records can be leaned upon in order to recover the subject of the damaged painting in Concepción, Chile.

\section{The Miraculous Meal Recounted by the Biographers of Diego de Alcalá}

Under unclear circumstances, the canvas in the collection of the Pinacoteca de la Universidad de Concepción now titled Monks Beneath a Tree was trimmed on at least three sides and a significant section of its foreground was removed. For this reason, the only known facts regarding its subject are self-evident, that is, it portrays two friars in an outdoor setting who wear the hooded habit and knotted cord of the Franciscans. ${ }^{4}$ Lacking vital clues once supplied in the foreground, art historians have suggested that the scene conveys penitence during the saint's final years at Alcalá de Henares (Pinacoteca Universidad de Concepción 2011). In what follows, I question this identification and instead propose that the cropped canvas depicts a small miracle that occurred in southern Spain just prior to the 1450 jubilee in Rome.

The minor wonder shown in the partial canvas in Concepción, as I contend, is a heaven-sent meal which the saint encountered during an arduous journey. This extraordinary incident was interpreted by Diego de Alcalá's biographers as a touchstone that demonstrated his faith and exemplary conduct (Ribadeneira 1704, p. 301). Francisco Peña (1594, pp. 14v-15v) and Melchor de Cetina (1609, pp. 27-28) both understood this miracle to have transpired following Diego's return to Spain from the Canary Islands in perhaps 1449. As recounted by Peña and Cetina, during this era, Diego was posted to Our Lady of Loreto near Seville, and on one occasion, the lay brother set off in the company of a colleague to the port town of Sanlúcar de Barrameda near Cadíz. Although the Gaudalquivir River proportioned a comparatively rapid and comfortable route to the coast the friars feared they would encounter negative influences along this well-traveled watercourse, a trepidation which moved them to travel by foot along a remote road. Lacking provisions to sustain their journey, the duo rapidly became fatigued from hunger, and Diego reassured his companion that they would soon find a meal through generosity or divine intervention. As the pair became increasingly famished, they recounted the loaves and fish that satisfied five thousand in the desert and the bread-toting raven that aided Saint Paul in the wilderness. As is certainly depicted in the fragmentary canvas in Concepción, the friars were rewarded for their faith; they soon came upon an unattended road-side spread of bread, plated fried fish, and wine, all carefully arranged upon (or wrapped in, depending

4 https://www.surdoc.cl/registro/100-102, accessed 3 October 2018. 
upon the source) an immaculate white cloth. While bread, fish and wine all resonate with Christian symbology, the first of these also prefigures Diego's acclaimed transformation of common rolls, pilfered for the poor from the refectory table at Alcala de Henares, into stunning roses.

While the cloth and miraculous meal described by Peña and Cetina were certainly shown in the foreground of cropped painting under study, an angel rendered in the painting's lower corner is absent from their accounts. First published in 1599-1610, Pedro de Ribadeneira's Flos Sanctorum (1704) presents an alternative strand of the episode in which Diego's gift is said to have been delivered "by the hand of angels" ("por mano de Ángeles") (p. 300). A theatrical interpretation of Diego's life by Juan Francisco Manuel (n.d.) seemingly exemplifies the dramatic potential of this divine intercessor in the Spanish baroque imagination. Likely produced under the siglo de oro, the theater script includes stage directions prescribing how, as Diego and his companion approached the site of the miracle, an angel was to descend from the rafters with a plate of provisions in hand. Upon setting this plate upon the stage, the angel was to astonish audiences with a spectacular departure by "ascending with velocity" ("ascendiendo con velocidad") (p. 2). In the painting under study, the fleeting role of the angel has been amended, as he lingers to gaze at Diego and to support a textual cartouche just visible in the lower right corner. Prior to the removal of this painting's borders and foreground, this putto established a critical visual connection for audiences that linked the textual description which he sustained to the iconographies toward which he gazed and gestured.

\section{Engraved Prototypes for a Miraculous Meal: Two Sources for Monks Beneath a Tree}

How Diego's culinary miracle was represented in Europe and in what format it arrived to the Viceroyalty of Peru as a source for the partial canvas now in Concepción are the subjects of the following section of this essay. I hope to forward a convincing argument that the cropped painting Monks Beneath a Tree can be situated in relation to two engraved prototypes produced in Antwerp, one by Adriaen Collaert after an oil painting by Maarten de Vos, and the other by Jan or Lucas van Doetechum after a painting by Pieter Bruegel the Elder. Confirmation of the painting under study as a rendering of Diego's 'miraculous meal' is perhaps best carried out by demonstrating its relationship to the first of these engravings. Furthermore, the attribution of this painting within the series of Diego de Alcalá in Santiago can be established by charting the iconographic genealogy of Diego's miracle forward in time and over generations from a mannerist altarpiece executed by Maarten de Vos for the former Franciscan church in Antwerp. Arguably the foremost painter in Flanders of his day, de Vos received a flurry of altarpiece commissions during the second half of the sixteenth century to replace artworks destroyed under the Protestant iconoclasm of 1566 (Shoaf 1980, p. 237; van der Linden 2015). Among the many commissions received by de Vos, the multipaneled devotional piece for the Franciscans of Antwerp representing the life of Saint Didacus (the Latin form of Diego de Alcalá), which he executed in oil on panel during approximately 1591-1600, was among his final works (Košak 2016, p. 30).

In its arrangement, de Vos's polyptych is tied to the medieval altarpieces of Saint Francis of Assisi, with a central panel showing a full-figure double portrait of Saint Francis and Saint Diego surrounded by eleven smaller panels to illustrate the life of Saint Diego (Košak 2016, p. 30). Produced in large part to engage an illiterate lay audience in the ritual of Catholic mass, such altarpieces functioned to draw attention to the focal space of an altar and to designate the holy persons and saints to whom the altar was dedicated. The mannerist altarpiece on the theme of San Diego is characterized by elongated figures in contrived poses and by vibrant hues drawn from the Venetian painting tradition, traits that may have heightening the appeal of these sacred scenes for Christian audiences.

Among the eleven small-scale panels that adorn this altarpiece, a scene showing Diego and his companion in a lush landscape goes almost unnoticed for its subtle olive-green and grey palette (Figure 2). The figure of Diego occupies the center of the composition, his future sainthood prefigured by a halo, while behind him his companion carries a 
bound volume. This small painting shows the moment during their journey when, having emerged from a forested stretch of road into a clearing, the stiffly-posed travelers encounter a modest feast of bread and plated fish staged at their feet upon a white cloth. Here, de Vos has drawn upon the gesture of Diego in order to convey the meal's heavenly origin; Diego extends his left arm downward as if to partake in its contents while raising his right arm towards the heavens, palm outward in blessing or gratitude. The meal's modest contents constitute an austere Flemish still life and invite formal comparisons with Diego and his companion; the elongated forms of silvery fish and the contours of the wine bottle are oddly suggestive of the friars' robed figures and impossibly small heads. Like the entirety of de Vos's altarpiece, the 'miraculous meal' panel forwarded an expressive and contrived visual language to Flemish audiences of the early seventeenth century in which the traveling Franciscans were relatable, if slightly peculiar models of Christian faith.

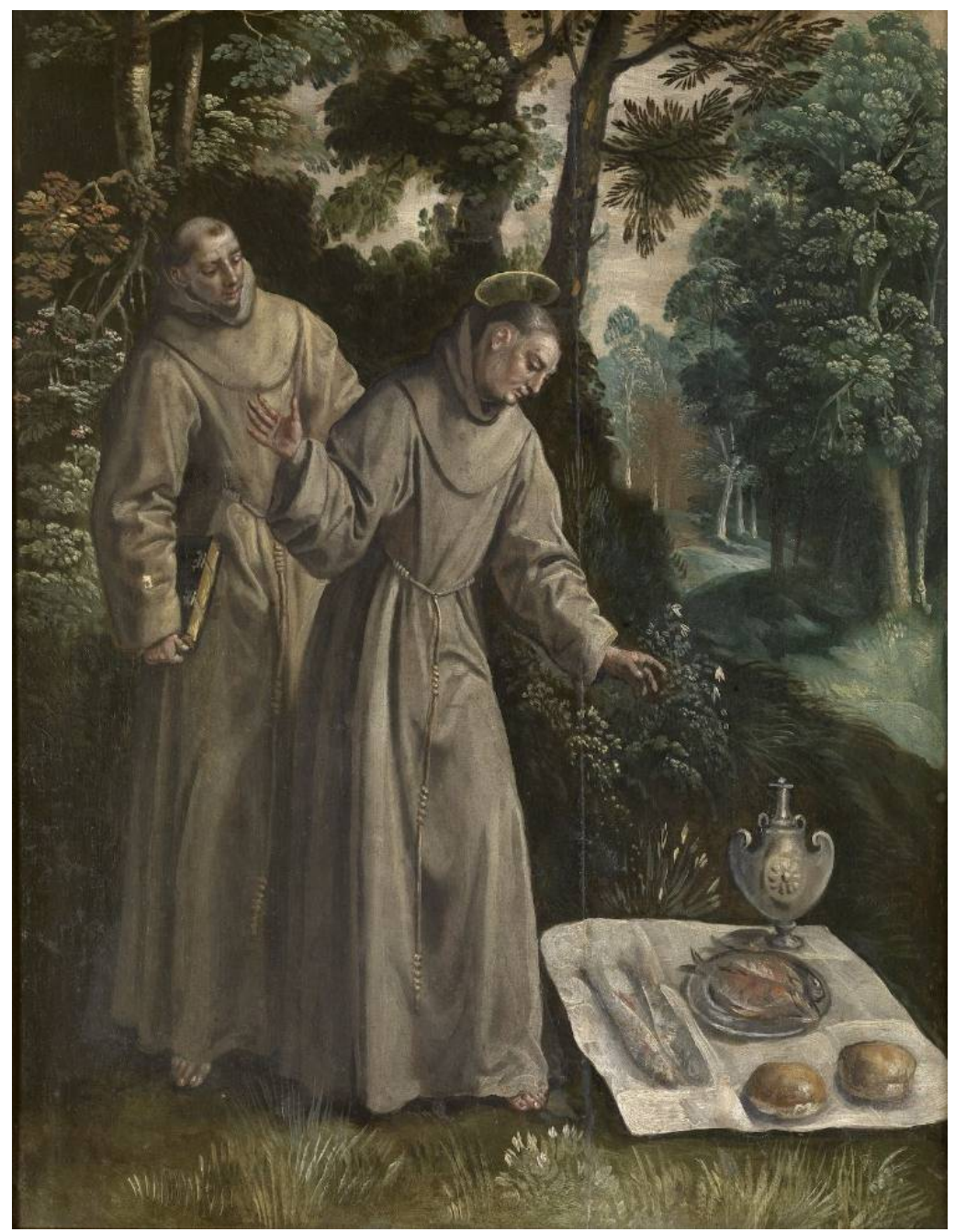

Figure 2. Maarten de Vos. In the Clearing of a Forest, Didacus Finds Bread, Fish and Wine, from the altarpiece The Story of Saint Didacus of Alcalá. 1591-1600. Oil on panel. Artwork in the public domain (Creative Commons); image courtesy of Royal Museum of Fine Arts in Antwerp/Koninklijk Museum voor Schone Kunsten Antwerpen-www.artinflanders.be (accessed on 1 October 2020)—Photo by Dominique Provost.

The influence of Maarten de Vos on the art of the Spanish Americas was immense, perhaps only surpassed by that of Rubens (Soria 1948, p. 258; Mesa and Gisbert 1977, p. 22). Evidencing his popularity and reach, de Vos's painted works were widely disseminated in Europe and the Americas as engravings, and his altarpiece on the life of Saint Didacus was no exception. By the order of Flemish Franciscan Henrik Sedulius (born Henrik de 
Vroom, 1549-1629), the altarpiece representing the life of Diego de Alcalá was reproduced on a plate of copper by Flemish engraver Adriaen Collaert (Figure 3). Collaert's engraving maintained the essential arrangement of the altarpiece with its double portrait framed by vignettes, all reduced to fit a single sheet of paper. A noteworthy addition to de Vos's altarpiece is the Latin dedication from Sedulius to Spanish King Philip III (r. 1598-1621) inserted beneath the imagery to celebrate this monarch's power and his tireless defense of the Catholic Church. As an iconographic counterpart to this dedication, the double portrait is capped by the coat of arms of the Spanish Crown. Indeed, Sedulius appears to have cleverly harnessed Collaert's print as propaganda to flatter the king and to garner continued royal support for the Franciscan Order.

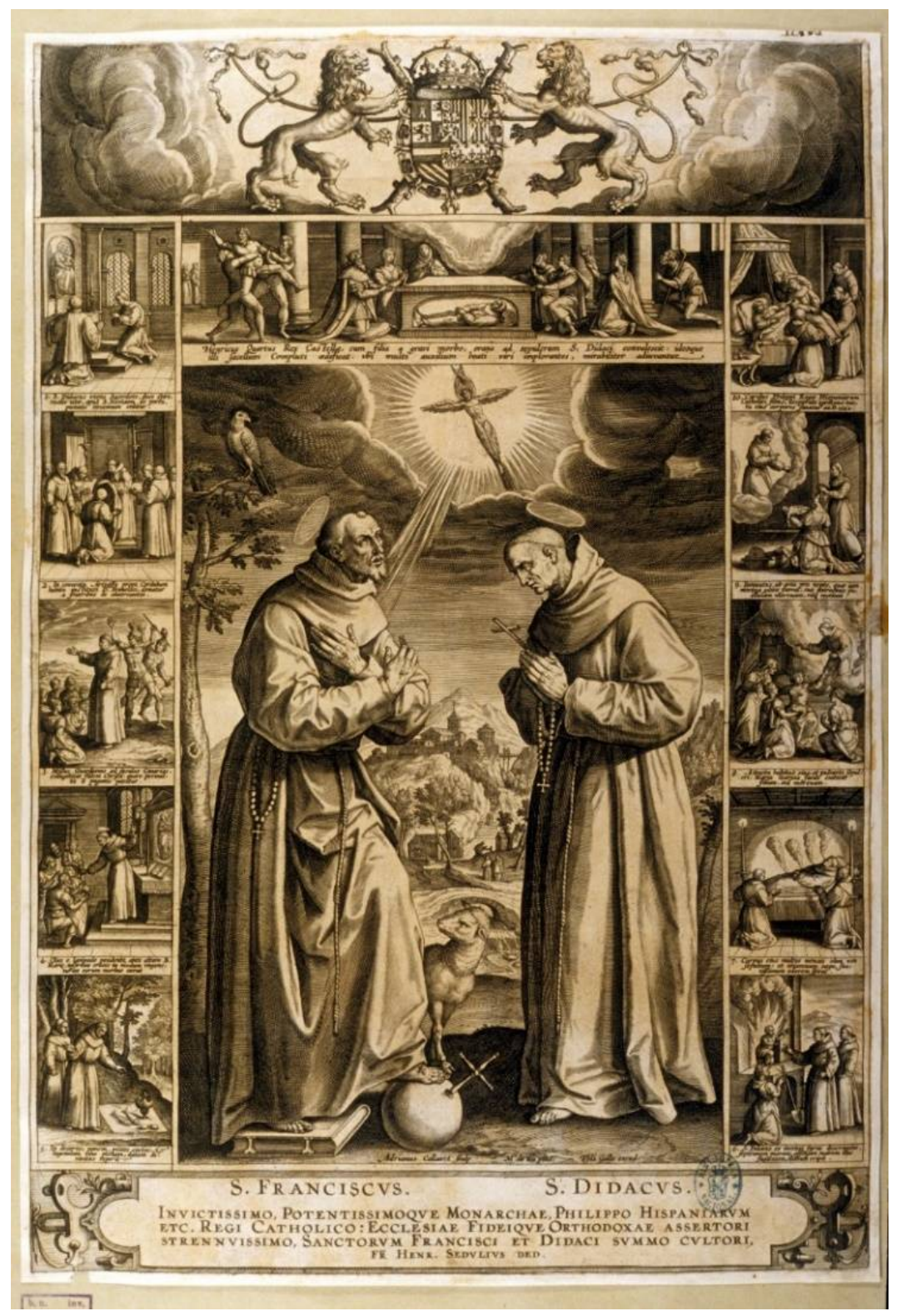

Figure 3. Adriaen Collaert (engraver) and Philips Galle (printer) after Maarten de Vos. S. Franciscus, S. Didacus. Dedication by Henrik Sedulius. ca. 1600-1618. Engraving on paper. $422 \times 288 \mathrm{~mm}$. Artwork in the public domain; image courtesy of the Biblioteca Nacional de España.

Collaert's reduction of de Vos's multipaneled altarpiece on a single copper plate implies important shifts in materiality and scale that rendered its iconography highly portable. In the early modern Andean world, such prints were predominantly imported 
for conventual and private collections where they served as loose models for paintings, sculptures, and other art forms. As Kelly Donahue-Wallace (2012, p. 416) has forwarded, Jesuit founder Ignacio de Loyola promoted a conception of engravings that held them to indelibly 'print' ideas upon the heart and the mind, a characteristic which made them ideal for the dissemination of religious doctrine in the Spanish Americas. By copying engraved models, the Andean painters who produced the series of Diego de Alcalá tapped into what has been termed the "pedagogical efficacy" of prints (Donahue-Wallace 2008, p. 334), furthering the dissemination of its messages among impressionable audiences of the Colegio de San Diego. With the aim of not only transmitting but also fixing a set of concepts upon the youth of this school regarding the centrality of missionization to the Franciscan Order and the relevance of faith as a catalyst for the spread of Christianity in Chile, Collaert's itinerant engraving showing the life of San Diego de Alcalá was utilized by unknown painters in Cusco as a primary source for the San Diego de Alcalá cycle. These painters transformed some or all of the vignettes that occupy the borders of Collaert's engraving into large-format canvases, and adapted the essence of de Vos's multipaneled altarpiece for the southern Andean context. ${ }^{5}$

Shown at the lower left section of Collaert's print, the tiny insert of the miraculous meal in the forest (Figure 4) corresponds to compositional features conveyed in Monks Beneath a Tree. Close attention to this vignette, labeled with the numeral 5 and titled In $A$ Clearing, a Divine Gift of Bread, Cooked Fish and Wine is Discovered, reveals the consequences of scale reduction and loss of color. Readily identifiable changes to the print include a significant loss of the details that once provided visual interest to this scene. The transition from the painted to printed medium reduced de Vos's composition to its essential formal elements. To draw attention to the focal motif of the white cloth and the items upon it, Collaert crafted a heavily cross-hatched middle ground that also establishes a string diagonal through the composition. Emulating this diagonal, Diego's gestures are a welcome hold-over from the de Vos painting that link the saint to the miracle at his feet. Stripped of the mannerist flourishes and coloration that characterized de Vos's painting, the remaining composition condensed in Collaert's engraving was just sufficient for transmitting the scene's essence to Cusco.

The painters of Cusco reconstituted the figural arrangement supplied by Collaert, reproducing its composition in reverse. ${ }^{6}$ Despite this change, their formal similarities permit the firm identification of the painting's subject as the miraculous meal encountered by Diego de Alcalá on the road between Seville and Sanlúcar. It seems natural that an imported engraving comprised of numerous miniscule scenes would to be 'unpacked' in Cusco by isolating and enlarging each scene upon its own canvas as part of an ordered series. Yet the painting Miracle of San Isidro the Farmer (1663) by Basilio de Santa Cruz Pumacallao in the Cusco Cathedral, in which ten miniscule episodes of San Isidro's life surround his focal portrait, demonstrates that the first scenario was only one option. Undeniably, the experience of viewing a hagiographic series in each of these two formats is significantly different. In one case, a small-format print or painting comprised of numerous scenes commands intimate, stationary, and likely solitary inspection. On the other hand, an extensive cycle of large-format paintings would have been distributed in a prescribed order across the corridors surrounding the colegio's paired patios or through several rooms, thereby designating these spaces as a united visual field. Furthermore, this painting cycle united the student body of the Colegio de San Diego in a shared spectatorial experience,

5 In addition to the miraculous meal episode treated in this study, other vignettes from Collaert's engraving that were reproduced in whole or in part within the San Diego cycle in Santiago include San Diego Saves a Boy from a Burning Oven (Episode 8), San Diego Converts Infidels in the Canary Islands (Episode 12), San Diego and his Mortifications (Episode 26 upper left detail), San Diego Heals the Sick with the Oil of the Lamp ... (Episode 27), San Diego Aids the Poor, the Sick, and the Lepers (Episode 31, figures), The Wake of San Diego Held by the Franciscans (Episode 42), and Don Carlos, Son of King Philip II, is Healed by the Presence of the Body of San Diego (Episode 47).

6 It is noteworthy that none of the other paintings in the Diego de Alalcá series that were based upon the Collaert print are carried in reverse, as this suggests a preference for this change on the part of the painters themselves. 
and dictated that this audience move through a highly curated circuit that may have inflected the daily routines of student life.

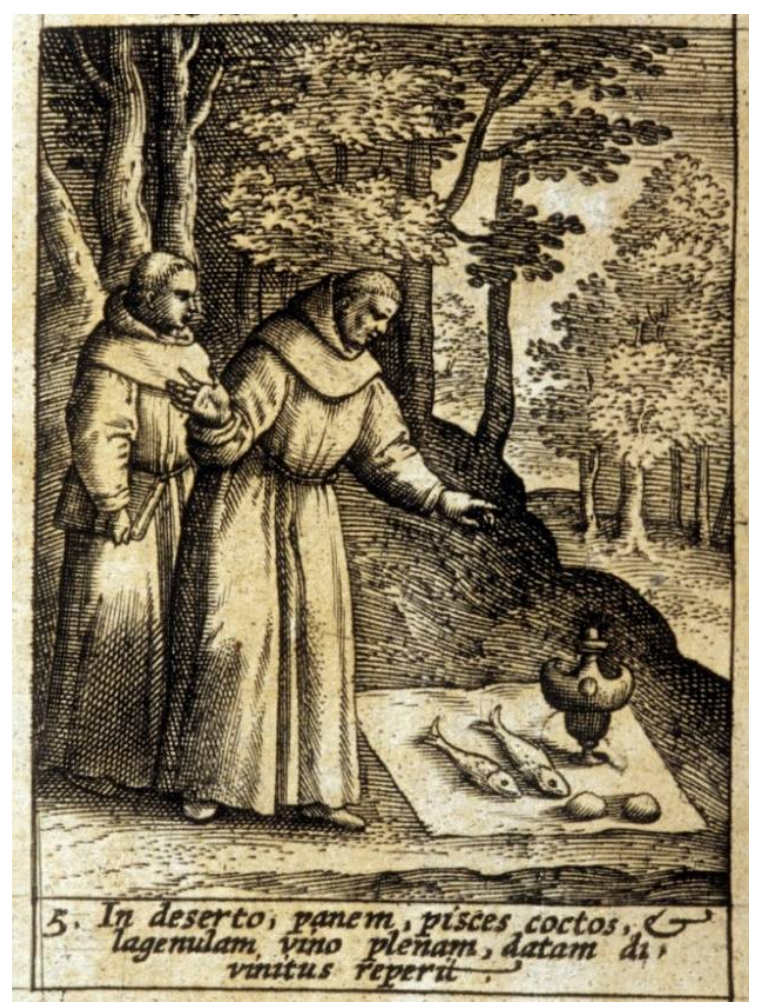

Figure 4. Adriaen Collaert (engraver) and Philips Galle (printer) after Maarten de Vos. In deserto, panem, pisces coctos, lagenulam, vino plenam, datam divinitus reperit (In A Clearing, a Divine Gift of Bread, Cooked Fish and Wine is Discovered), detail from S. Franciscus, S. Didacus. ca. 1600-1618. Engraving. Artwork in the public domain; image courtesy of the Biblioteca Nacional de España.

A related feature of Collaert's engraving that was adapted by the workshop at Cusco for their painting cycle was the sequential numbering of each episode. Importantly, the practice of numbering each painting's cartouche clarified the order in which the forty-seven episodes of this extensive cycle were to be displayed and viewed. In other words, this numbering system guided audiences through the life of this saint as established in existing images and literary hagiographies. These visualizations of the school's namesake arranged throughout campus forwarded Diego de Alcalá as a unifying symbol for the student body and promoted the Seraphic values of austerity and faith which he exemplified. Assuming that the sequence of events recounted by the biographers of Diego de Alcalá was retained by the artists of Cusco, then the 'miraculous meal' episode occupies the seventeenth position in the series, wedged between Diego's stint as a missionary to the Canary Islands and his pilgrimage to the Roman jubilee of 1450.

A noteworthy difference between Collaert's engraving and the painting Monks Beneath a Tree which it inspired is the evident shift in scenery, a change that suggests the influence of a second engraving selected to more closely reflect the surroundings of Cusco and Santiago. In what was an effective strategy for rendering the life of Diego de Alcalá more relatable for local audiences, the painters of Cusco disregarded the unfamiliar wooded backdrop proposed by Collaert's print and instead made use of a mountain landscape sourced from the Flemish series of engravings The Large Landscapes published by Hieronymus Cock. Specifically, the backdrop for Monks Beneath a Tree was adapted from an engraving that appropriately reflects the theme of travel titled Milites Requiescentes (Soldiers at Rest) by Jan 
or Lucas van Doetechum after a painting by Pieter Bruegel the Elder (Figure 5). ${ }^{7}$ The composition of this print is dominated by a hill topped with a single tree that slightly obscures the sweeping mountain view behind it. Beneath the tree, the hill's slopes are populated by traveling figures who provide a sense of nature's immensity; while soldiers rest in the open air, a peasant couple hurries on to the village below. The engraving's descriptive landscape had already inspired Flemish artists, such as the painter Abel Grimmer who had adopted its focal arboreal motif in works such as Landscape with Town (1606). A full century later, this engraving provided the artists of Cusco with the focal tree in the center of the composition as well as the mountain backdrop observed in Monks Beneath a Tree. Thus, while one Flemish engraving provided the hagiographic theme and figural grouping for the painting in Concepción, a second engraving on the theme of a journey on foot rendered its setting familiar for Andean viewers.

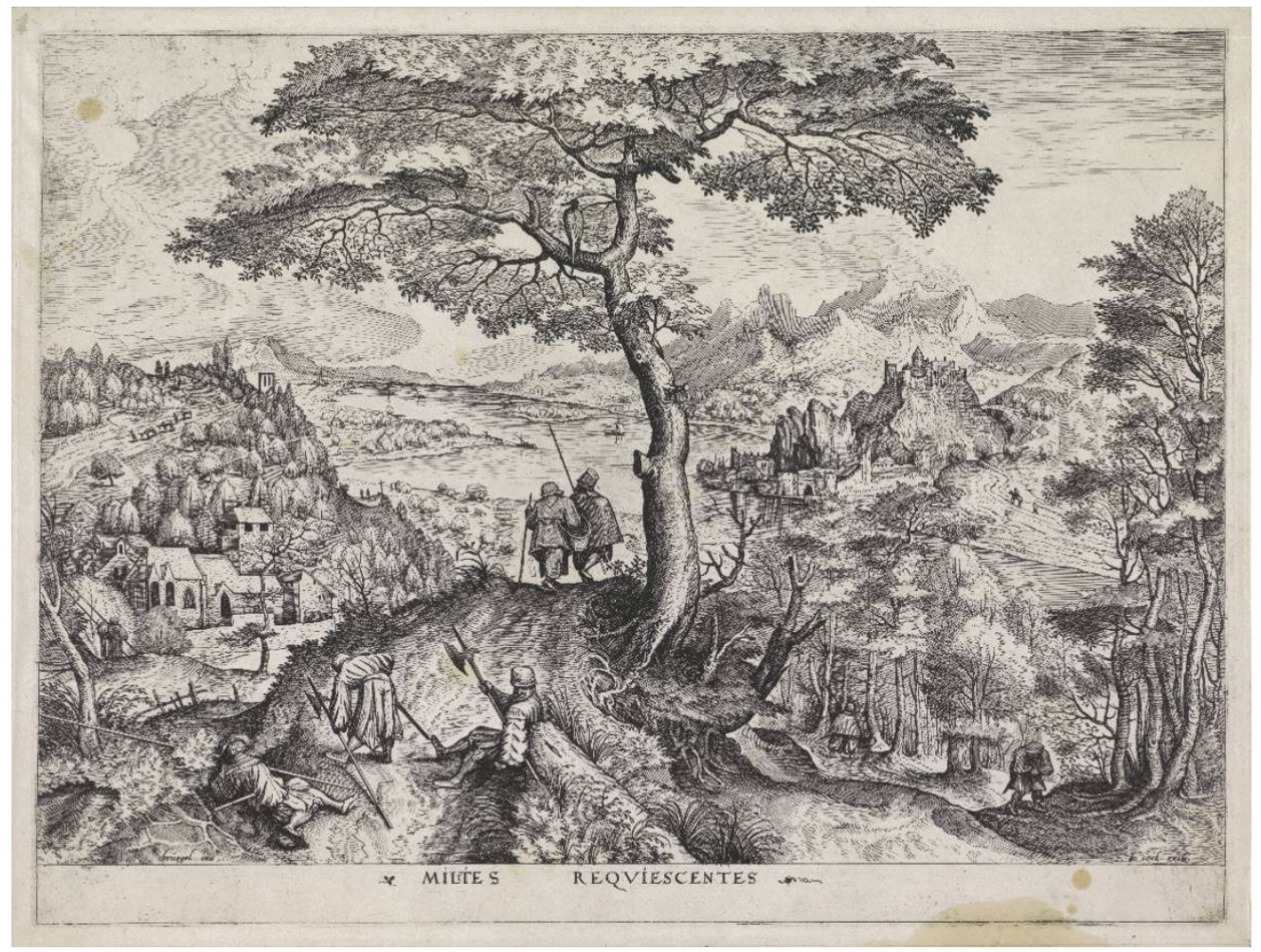

Figure 5. Jan or Lucas van Doetechum after Pieter Bruegel I. Milites Requiescentes (Soldiers at Rest) from the series Great Landscapes. Antwerp, 1553-1558. Engraving on paper. $32.5 \times \mathrm{w} 44.2 \mathrm{~cm}$. Artwork in the public domain; image courtesy of the Rijksmuseum, Amsterdam.

\section{Sources Served on a Plate: Emulating Engravings and Paintings on Copper}

The fundamental role of Flemish engravings as a principal inspiration for the arts of the Viceroyalty of Peru has long been established in academic literature (Mesa and Gisbert 1962, p. 33; Cruz de Amenábar 1986, pp. 55-59; Stastny Mosberg 2013, pp. 364-68; Dean 1996; Ojeda di Ninno 2009; Michaud and Torres Della Pina 2009). In the midst of Antwerp's religious turmoil at the end of the seventeenth century, the exportation of prints became an important means by which Flemish artists could earn a living. Under these tumultuous circumstances, a thriving market for prints originated in Antwerp and extended to artistic centers in the Americas by way of Spanish port towns. For their rapid and widespread circulation, Stephanie Porras (2016) has aptly characterized the movement of prints from Antwerp to the Americas as 'viral'.

\footnotetext{
7 For more information on the landscape engravings produced by Jan and Lucas van Doetechum, see Onuf (2014).
} 
While Flemish engravings were critical models for the production of Andean paintings, they were not the only influential sources to have emerged out of Antwerp's print making industry. Oil paintings on copper, often produced on the smooth reverse of defunct engraved plates, are another Flemish art form that had an important impact upon the colonial paintings produced in highland Peru (Mesa and Gisbert 1977, pp. 24-25; Bargellini 1999; Stratton-Pruitt 2017, pp. 16-22). In Antwerp, an important source of paintings on copper supports was the workshop of the Forchaudt family, which not only produced engraved plates but also sent small-scale paintings on copper to Spanish port cities, where some were exported to the Americas. Furthermore, some of the Italian artists who arrived to the Viceroyalty of Peru had adopted this technique, thereby influencing stylistic development at workshops in Lima, Cusco, and Potosí (van Ginhoven 2015; Stratton-Pruitt 2017, pp. 16-22). A well-known example is Mateo Pérez de Alesio, who arrived to Peru from Rome in 1589. In Lima, he repurposed a copper plate, which he had engraved with a scene of the Holy Family while still in Rome, by painting an image of the Virgen de la Leche (the Virgin of the Milk) on its reverse (Wuffarden 2014a, pp. 264-65).

In large part for their durability and modest scale, paintings on copper enjoyed a wide distribution in the Spanish Americas as vibrant complements to monochromatic prints. Within the Andean sphere, a particularly appealing feature of paintings on copper was the attractive blue-toned mountain landscapes produced by Flemish painters and reproduced in Spanish and Italian works. As Clara Bargellini (1999) has documented, at least a handful of paintings on copper found their way to the highland Andes. In addition, the Flemish tradition of painting on copper inspired Spanish and Italian artists as well as artists in the Spanish Americas (Sullivan 1996, pp. 31-32). One illustrative example is Italian painter Bernardo Bitti, who produced works in Peru that featured landscapes derived from the Flemish style such as Agony in the Garden (ca. 1595-8) (Wuffarden 2014a, pp. 262-63). In lieu of adopted the expensive technique of applying oils onto copper plates, a far more common practice in the workshops of Cusco was likely the replication on canvas of their landscape features and singular vaporous aesthetic. ${ }^{8}$ One such instance was perhaps the painting fragment in Concepción, in which the crags and tails provided by van Doetechum's engraved mountain vista may have been embellished with cool blue-grey hues not unlike those observed in Flemish landscape paintings on copper (see Figures 1 and 5).

Despite the clear influence of the Antwerp print market on Monks Beneath a Tree (or perhaps San Diego's Discovery of a Miraculous Meal), it is important to emphasize that this painting is far more complex than a mere reproduction of its Flemish inspirations. It might be said that Flemish prints provided the compositional armature upon which Cusqueñan painters sutured an array of styles and influences in a regional artistic repertoire. Indeed, Monks Beneath a Tree as well as the other paintings of this series are perhaps best understood as a network of interlocking citations adapted from imported and local sources. ${ }^{9}$ To note an additional European influence, the heavy contemplative figures of San Diego and his companion reflect the still presence and earthen palette used by Spanish baroque artists such as Jusepe de Rivera and Francisco de Zurbarán. These figures may have been informed by the serene hagiographic subjects found among Zurbarán works in various churches within the Viceroyalty of Peru (Kinkead 1984, p. 305). Also important was the influence of the local indigenous artistic tradition, as evidenced by the bird perched among the branches of the tree. A detail adapted from the van Doetechum engraving, this creature was transformed through the application of brilliant color into an imaginative local species

8 An illustrative example of the Flemish landscape aesthetic derived from paintings on copper is found in Italian painter Bernardo Bitti's Agony in the Garden, ca. 1595-8, which was created in the Viceroyalty of Peru. Here, Bitti layered the blue tones that had become popular among Italian artists over a compositional framework supplied in a print by Crispijn van den Broeck (1523-89/91).

9 A notable characteristic of the Diego de Alcalá series under study is the manner in which its episodes are grouped thematically such that each set of episodes reflects different stylistic influences, perhaps suggesting that they were carried out by different artists. For instance, outdoor scenes produced to illustrate Diego's stint in the Canary Islands lean heavily upon Flemish landscape paintings, while the interior scenes at Alcalá de Henares reflect heavier Spanish and Italian baroque influences. 
that resonating with indigenous avian motifs reproduced in colonial textiles and kero vessels (Gisbert 2008, pp. 149-61). The colorful wings of the cherub are another feature of local style that restaged Monks Beneath a Tree from southern Spain to the southern Andes. Angelic and avian beings were interrelated in the colonial Andean worldview, and may have even overlapped conceptually with indigenous celestial deities. The precise reason for the colonial-era popularity of angels and birds among the indigenous peoples of highland Peru is unclear, but may be tied to their traditional role as intercessors between the celestial and earthly realms (Gisbert 2008, p. 103). In any case, the idyllic Andean landscape that was conveyed in local artistic representations such as Monks Beneath a Tree likely resonated with the Christian conception of Eden before the fall as a garden populated with winged creatures (Gisbert 2008, pp. 149-81).

\section{Conclusions}

This study has presented new approaches to the familiar question of how Flemish print sources were employed by artists of the Latin American colonial world as models for emulation. Through an examination of the notarial contracts of Cusco between patrons and artists, this study has established a firmer groundwork for understanding the centrality of prototypes for artistic commissions. While confirming the role of patrons in sourcing models, contracts also reveal that such models took on a variety of formats beyond the familiar engraving. Of particular importance to the present study, contracts often established that, by law, a completed commission was to be a close reproduction of a specified model. Hence, one motive for entering into such a contract was the security that it provided both clients and artists by fixing, before a notary, expectations regarding the product of a transaction and its compensation. While a methodology that gives weight to the centrality prototypes in the painting practices of colonial Cusco may appear to privilege the European model, I have argued that such a methodology in fact opens onto a decolonial vantage point by highlighting the gaps between a source and its copy where artistic liberties are embedded.

With the notarial contracts of colonial-era Cusco in mind, this study has proposed an innovative approach to determining the subject of artworks which have been damaged or separated from their series. The recovery of such information contributes to the restoration and protection of national patrimony, a theme which been complicated in Latin America by what Mundy and Hyman (2015) have referred to as "colonialism's unique legacy" (p. 308). By identifying two models that served as likely sources for a cropped colonial painting in Concepción, Chile, this study has clarified how engravings can fill in missing elements of a composition or figural arrangements of a partial canvas. Moreover, the discovery of the subject of the cropped painting Monks Beneath a Tree as a scene from the life of Diego de Alcalá confirms its attribution as a missing episode from the colonial cycle dedicated to this saint in Santiago, Chile. This attribution also suggests that additional lost episodes from the same series may be suggested by closely examining Collaert's print. By examining the characteristics that set Monks Beneath a Tree apart from its engraved sources, we can also move toward casting the Diego de Alcalá series as a highly creative undertaking that adapted a myriad of artistic traditions for a local audience. Among these traditions, Spanish painting, Flemish landscapes on copper, and local indigenous iconographies can all be identified as sources, and this array of influences is frankly so complex as to reframe derivation itself as a creative process. Going forward, there is a variety of information that remains to be uncovered regarding the series of paintings on the life of Diego de Alcalá in Santiago. Because we stand to learn so much regarding this series' visual sources, its artists in Cusco, and its student audience at the Colegio de San Diego, it is hoped that future engagement with the colonial archives of both cities will shed additional light on these themes.

Funding: The revision stage of this article is funded by Fondecyt ID1210898 (Chile).

Institutional Review Board Statement: "Not applicable" for studies not involving humans or animals.

Informed Consent Statement: “Not applicable” for studies not involving humans. 
Data Availability Statement: Data available in a publicly accessible repository: Centro de Documentación de Bienes Patrimoniales de Chile, www.surdoc.cl, accessed on 1 October 2020, reference number 100-102.

Acknowledgments: This paper has benefitted from two anonymous referees, co-editors Lauren Beck and Alena Robin, Mari Carmen García-Atance, Álvaro Bustos, Amalia Castro, Fanny Canessa, and archivist Muriel Torres.

Conflicts of Interest: The authors declare no conflict of interest.

\section{References}

\section{Archive and Unpublished Sources}

Archivo Histórico Franciscano Rigoberto Iturriaga C., Santiago, Chile (AHF).

\section{Published Sources}

Bargellini, Clara. 1999. Painting on Copper in Spanish America. In Copper as Canvas: Two Centuries of Masterpiece Paintings on Copper, 1575-1775. Edited by Michael K. Komanecky. New York and Oxford: Oxford University Press, pp. 31-44.

Cetina, Melchor de OFM. 1609. Discursos Sobre la Vida y Milagros de del Glorioso Padre San Diego, de la Orden del Seráfico padre S. Francisco. Madrid: Luis Sánchez.

Chichizola Debernardi, José. 1983. El Manierismo en Lima. Lima: Pontifica Universidad Catolica del Perù.

Cohen-Aponte, Ananda. 2017. Decolonizing the Global Renaissance: A View from the Andes. In The Globalization of Renaissance Art: A Critical Review. Edited by Daniel Savoy. Leiden: Brill, pp. 67-94.

Cornejo Bouroncle, Jorge. 1952. Arte cuzqueño (Segunda mitad del siglo XVII). Revista del Archivo Histórico del Cuzco 3: 66-140.

Cornejo Bouroncle, Jorge. 1960. Derroteros de Arte Cuzqueño: Datos Para una Historia del Arte en el Perú. Cuzco: Ediciones Inca.

Crider, John Alan. 1991. Indians and Artistic Vocation in Colonial Cuzco, 1650-1715. UCLA Historical Journal 11: 51-68.

Cruz de Amenábar, Isabel. 1984. Arte: Lo Mejor en la Historia de la Pintura y Escultura en Chile. Santiago: Editorial Antártica S.A.

Cruz de Amenábar, Isabel. 1986. Arte y Sociedad en Chile 1550-1650. Santiago: Ediciones Universidad Católica de Chile.

Damian, Carol. 1995. Artist and Patron in Colonial Cuzco: Workshops, Contracts, and a Petition for Independence. Colonial Latin American Historical Review 4: 25-53.

Dean, Carolyn S. 1996. Copied Carts: Spanish Prints and Colonial Peruvian Paintings. The Art Bulletin 78: 98-110. [CrossRef]

Díaz, Fr. Bernardino. 1920. Ynventario de ... salas y oficinas del convento franciscano de Nuestra Señora del Socorro de Santiago de Chile (Inventory of ... rooms and offices of the Franciscan convent of Our Lady of Mercy). Unpaginated manuscript. AHF, A-1 $4 \mathrm{o} \mathrm{B} / 12$.

Donahue-Wallace, Kelly. 2008. Picturing Prints in Early Modern New Spain. The Americas 64: 325-49. [CrossRef]

Donahue-Wallace, Kelly. 2012. Spinning the King: Prints, Imprinting and the Equestrian Portrait of Charles IV. Print Quarterly 29: 411-16.

García-Atance de Claro, Mari Carmen. n.d. San Diego de Alcalá: “Asceta de Cristo, místico de María” Milagros de sanación en el barroco hispanoamericano. Unpublished manuscript. 111p.

Gisbert, Teresa. 2008. El Paraíso de los Pájaros Parlantes: La Imagen del otro en la Cultura Andina. La Paz: Plural Editores. First published in 1999.

González, Fr. B. 1925. Nuevo inventario del Convento de Socorro, Santiago de Chile (New inventory of the Convent of Succor, Santiago, Chile). Unpaginated manuscript. AHF, A-1 $4^{\circ} \mathrm{B} / 12$.

Hyman, Aaron. 2017. Inventing Painting: Cristóbal del Villalpando, Juan Correa, and New Spain's Transatlantic Canon. The Art Bulletin 99: 102-35. [CrossRef]

Iturriaga Carrasco, Rigoberto. 1990. El Colegio San Diego de Alcalá. Santiago: Publicaciones del Archivo Franciscano.

Kinkead, Duncan T. 1984. Juan de Luzón and the Sevillian Painting Trade with the New World in the Second Half of the Seventeenth Century. The Art Bulletin 66: 303-12.

Košak, Tina. 2016. St. Diego of Alcala's Miraculous Healing. The Altar Painting by Pietro Mera in the Church of St. Anne in Koper and its Stylistic and Iconographic Context. Annals for Istrian and Mediterranean Studies 26: 25-42.

Manuel, Juan Francisco. n.d. Comedia Famosa: El Canonizado en Vida [San Diego de Alcalá], No publisher provided.

Marcos Mira, Hernán [Hernán Rodríguez Villegas and Isabel Cruz de Amenábar]. 1977. La serie de San Diego de Alcalá. Suplemento literario, artístico y científico. El Mercurio, April 24.

Mebold Koenenkamp, Luis. 2010. Catálogo de Pintura Colonial de Chile. Santiago: Ediciones UC, vol. 2.

Mesa, José de, and Teresa Gisbert. 1962. Historia de la Pintura Cuzqueña. Buenos Aires: Universidad de Buenos Aires, vol. 1.

Mesa, José de, and Teresa Gisbert. 1977. Holguín y la Pintura Virreinal en Bolivia, 2nd ed. La Paz: Librería Editorial Juventud.

Michaud, Cécile, and José Torres Della Pina, eds. 2009. De Amberes al Cusco: El Grabado Europeo Como Fuente del Arte Virreinal. Lima: Impulso Empresa de Servicio SAC.

Mundy, Barbara E., and Aaron M. Hyman. 2015. Out of the Shadow of Vasari: Towards a New Model of the 'Artist' in Colonial Latin America. Colonial Latin American Review 24: 283-317. [CrossRef] 
Nolan, James L. 1978. Discovery of the Lost Art Treasures of California's First Mission. San Diego: Copley Books/The Copley Press.

Ojeda di Ninno, Almerindo. 2009. Las fuentes grabadas del arte colonial. Estado de la cuestión. In De Amberes al Cusco: El Grabado Europeo Como Fuente del Arte Virreinal. Edited by Cécile Michaud and José Torres Della Pina. Lima: Impulso Empresa de Servicio SAC, pp. 15-21.

Onuf, Alexandra. 2014. Old Plates, New Impressions: Local Landscape Prints in Seventeenth-Century Antwerp. The Art Bulletin 96: 424-40. [CrossRef]

Peña, Francisco. 1594. Tratado de la Maravillosa Vida, Muerte y Milagros del Glorioso S. Diego Confessor. Barcelona: Empresa de Jayme Cena.

Pinacoteca Universidad de Concepción. 2011. Pintura Colonial: Arte y Religiosidad Popular: Pintura y Escultura Siglos XVII y XVIII. Unpaginated Exhibition Catalogue, Colección Pinacoteca Universidad de Concepción. Concepción: Universidad de Concepción.

Porras, Stephanie. 2016. Going Viral? Maerten de Vos's St. Michael the Archangel. Nederlands Kunshistoriches Jaarboek 66: 54-78. [CrossRef]

Ribadeneira, Pedro de. 1704. Flos Sanctorum De Las Vidas De Los Santos, Escrito Por El Padre Pedro De Ribadeneyra, de la Compañia de Jesus, Natural de Toledo. Barcelona: Jayme Suriá Impressor, vol. 3.

Schenone, Héctor H. 1992. Iconografía del Arte Colonial. Los Santos and Buenos Aires: Fundación Tarea, vol. 1.

Shoaf, Jane V. 1980. A Seventeenth-Century Album of Drawings by Marten de Vos. Master Drawings 18: 237-52, $295-311$.

Soria, Martín. 1948. Some Flemish Sources of Baroque Painting in Spain. The Art Bulletin 30: 249-59. [CrossRef]

Stastny Mosberg, Francisco. 2013. Ulises y los mercaderos. Transmisión y comercio artístico en el Nuevo Mundo. In Estudios de Arte Colonial. Lima: Tarea Asociación Gráfica Educativa, vol. 1, pp. 351-78. First published in 1995.

Stratton-Pruitt, Suzanne. 2017. The Art of Painting in Colonial Bolivia 1600-1825. El arte de la pintura en la Bolivia colonial, 1600-1825. In The Art of Painting in Colonial Bolivia. El Arte de la Pintura en Bolivia Colonial. Edited by Suzanne Stratton-Pruitt. Philadelphia: Saint Joseph's University Press, pp. 1-67.

Sullivan, Edward. J. 1996. European Painting and the Art of the New World Colonies. In Converging Cultures: Art and Identity in Spanish America. Edited by Diane Fane. New York: The Brooklyn Museum and Harry M. Abrams, pp. $28-41$.

van der Linden, David. 2015. Coping with crisis. Career strategies of Antwerp painters after 1585. De Zeventiende Eeuw. Cultuur in de Nederlanden in Interdisciplinair Perspectief 31: 18-54. [CrossRef]

van Ginhoven, Sandra. 2015. Guilliam Forchondt and the role of the Greater Netherlands in the dissemination of Flemish art in Latin America. De Zeventiende Eeuw 31: 159-78. [CrossRef]

Vega, Lope de. 1988. San Diego de Alcalá: A critical and annotated edition by Thomas E. Case. Kassel: Reichenberger.

Verdi Webster, Susan. 2016. Materiales, modelos y mercado de la pintura en Quito, 1550-1650. Procesos: Revista Ecuatoriana de Historia 43: 37-64. [CrossRef]

Verdi Webster, Susan. 2017. Lettered Artists and the Languages of Empire: Painters and the Profession in Early Colonial Quito. Austin: University of Texas Press.

Villalon, L. J. Andrew. 1995. Putting Don Carlos Together Again: Treatment of a Head Injury in Sixteenth- Century Spain. The Sixteenth Century Journal 26: 347-65. [CrossRef]

Wuffarden, Luis Eduardo. 2014a. The Presence of Italian Painting, 1575-1610. In Painting in Latin America 1550-1820. Edited by Luisa Elena Alcalá and Jonathan Brown. New Haven and London: Yale University Press, pp. 257-73.

Wuffarden, Luis Eduardo. 2014b. Between Archaism and Innovation, 1610-1670. In Painting in Latin America 1550-1820. Edited by Luisa Elena Alcalá and Jonathan Brown. New Haven and London: Yale University Press, pp. 275-305.

Zimmerman, Klaus. 1994. DIDACUS (Diego) von Alcalá. In Lexikon der Christlichen Ikonographie. Edited by Karl Georg Kaster. Rome: Herder, vol. 6, pp. 54-55. First published in 1974. 